\title{
The case for helping Mexico - now
}

\begin{abstract}
The money crisis in Mexico is a great setback for civility in the Western Hemisphere and for hopes of greater US noncolonial influence in Latin America. The US Congress must first act on the loan guarantees asked of it.
\end{abstract}

LESS than a year ago, Mexico seemed on the brink of joining the rich countries of the world. At the time of this journal's survey of "Science in Mexico" (Nature 368, 789-804; 1994), there were several cheering tendencies to describe. The North American Free Trade Agreement (NAFTA) had been signed, and offered even greater benefits to Mexico than to its partners, the United States and Canada. Many industrial companies had independently discovered how to make money by exporting what they manufactured, and seemed destined to get on even faster. Science and technology had been given an honourable place near the centre of public affairs, and the means of awarding research funds (still too meagre) had been made fair, even imaginative. So why has Mexico seemingly collapsed, in just a few weeks, to the point at which bankers are worrying that it will have defaulted on its foreign debts by about now?

To be sure, there were clouds on the horizon last spring. Earlier in the year, there has been a rebellion against the civil governor of the southern state of Chiapas by Mexicans of indigenous descent, only temporarily settled and only then at some political cost to the government. More seriously, the then-impending election (held on 15 August), while advertised (by the Institutional Revolutionary Party, or PRI) to be less undemocratic than its predecessors, left much to be desired. But against the optimism endangered by the government's declared commitment to reform, these clouds seemed no bigger than a man's hand.

What has gone wrong is a simple miscalculation in economics. A year ago, Mexico was running its economy at a deficit with the rest of the world amounting to about 15 per cent of its gross domestic product, but was able to pay its bills because the inward investment of hard currency in its domestic enterprises roughly matched the deficit. At the time, nobody seemed particularly concerned. NAFTA could surely only increase the inward flow of hard currency? But, in the event, the inward flow actually diminished, perhaps because of the diversion of investment funds to other places, perhaps because of economic recovery in the United States. So Mexico's external spending was no longer covered by investment funds, the peso started to slide, investors lost confidence in their investments, the peso slid further ... and so on.

At the beginning of this week, Mexico's official holdings of foreign currency were said to be worth just US $\$ 2$ billion. Last week, the central bank even failed to sell the planned instalments of domestic debt that are denominated in US dollars so as to make them palatable, in uncertain times, to Mexicans. The calculation now is that Mexico needs $\$ 40$ billion to keep it afloat, and there is a provisional deal whereby the United States would provide loan guarantees for that amount. (Mexico would be required to repay the United States in oil if the guarantees were ever called in.) But the US Congress, in its new colours, may well decline to sanction the deal. That, of course, would kill off NAFTA. It may do much worse.

The United States has no formal obligation to help out, but every self-interested reason for doing so. Mexico is not merely its nearest neighbour to the south, but also one with which it is inextricably intertwined. The most conspicuous ties may be those of illegal immigration into Texas and California, but the cultural ties go back further, and are more permanent. That the United States is the chief provider of overseas $\mathrm{PhD}$ certificates to Mexicans is only one proof of the connection. But the opportunities that will be sacrificed if there is no loan guarantee put the past beyond the pale. NAFTA offered the United States the chance of a mutually beneficial relationship with a latin country to the south that would be so transparently free of the taint of colonialism that others would wish to follow. President Bill Clinton eloquently spelled out those hopes at the Latin-American summit meeting just two months ago. Everybody will be worse off if they come to nothing.

\section{Per ardua ad astra}

US astronomy faces impossible choices unless there is a little more to spend.

AstronOMY in the United States is in a bind. Resources are only meagre, and ill-matched with people in post. In an equitable world, US astronomers would draw some comfort from knowing that the problems are similar in Europe. But the world is not an equitable place. And the United States supports an even greater proportion of top-class research in astronomy and astrophysics than in, say, low-temperature physics. Worse, it is only four years since the National Academy of Sciences commissioned (at government behest) John Bahcall of Princeton to say what the next big spending should be. Now the National Science Foundation (NSF), which pays the bills, has put a damper on the proceedings with a report by a panel under Richard McCray (from the 